\title{
Comparative Study of Reporting for Transparency under International Agreements on Climate Change and Ozone Protection: The Case of the Philippines
}

\author{
Masato Kawanishi, Makoto Kato, Emiko Matsuda, and Ryo Fujikura
}

\begin{abstract}
Transparency is crucial for the effective implementation of the United Nations Framework Convention on Climate Change (UNFCCC) and the Montreal Protocol on Substances that Deplete the Ozone Layer. This paper examines the status of reporting for transparency by developing countries under these international regimes. In doing so, it selects the Philippines as a case, since the country is apparently late in the submissions of national reports under the UNFCCC. This study aims to identify possible factors hindering the Philippines from reporting as required under the Convention. To this end, it presents the results of a comparative study with the reporting by the Philippines under the Montreal Protocol by utilizing the framework of "enforceability analysis" as well as the concepts of "scale" and "scaling". The comparison in terms of five factors for enforceability finds that the data collection for reporting under the Montreal Protocol is relatively easier to implement in the Philippines. Furthermore, upscaling of the issue of climate change on the administrative scale is found to impose additional burden on capacity development in the country. The findings suggest an increasing need for donors to find a good balance between assisting developing countries deliver reports for transparency and facilitating their longer-term capacity development.
\end{abstract}

Index Terms-Climate change, ozone protection, reporting, transparency.

\section{INTRODUCTION}

Transparency is crucial to the effective implementation of international agreements [1]. It is referred to by [1] as "the generation and dissemination of information about the requirements of the regime and the parties' performance under it". As transparency heightens the extent to which behaviors and violations are visible to others, verification can help influence parties' behaviors, thereby contributing to the effectiveness of agreements [2]. Despite the importance attached to transparency, however, "it remains elusive in practice" [3]. As discussed by [1], under environmental treaties and other agreements, and particularly those with a high technical or scientific content, a failure to report is disproportionately high among developing countries, and it is

Manuscript received September 3, 2018; revised December 5, 2018. This work was supported by the Mitsui \& Co. Environment Fund and JSPS KAKENHI Grant Number 18H03449.

M. Kawanishi is with Japan International Cooperation Agency, Tokyo, Japan (e-mail: Kawanishi.Masato@jica.go.jp).

M. Kato and E. Matsuda are with the Overseas Environmental Cooperation Center, Tokyo, Japan (e-mail: kato@oecc.or.jp; matsuda@oecc.or.jp).

R. Fujikura is with the Faculty of Sustainability Studies, Hosei University, Tokyo, Japan (e-mail: fujikura@ hosei.ac.jp). attributed to a deficit of capacity rather than will. According to [4], international environmental agreements generally do not impose penalties for noncompliance. Instead, their principal enforcement mechanism is peer or public pressure generated from information on implementation that the parties themselves report to the agreements' secretariats. A failure of developing countries to report reflects their lack of personnel, resources, technical capability, and the data themselves. Reference [3] also indicates that the capacity to report depends not only on the characteristics of the actor providing that information but also on those of the information being requested.

Against this backdrop, the present study examines the status of reporting by developing countries under two international environmental agreements where reporting is a legal obligation for the parties: One is the United Nations Framework Convention on Climate Change (UNFCCC), and the other, the Montreal Protocol on Substances that Deplete the Ozone Layer. In doing so, this study selects the Philippines as a case, since the country is apparently late in the submissions of national reports under the UNFCCC, while it submits reports as scheduled under the Montreal Protocol. This study aims to identify possible factors hindering the Philippines from reporting as required under the UNFCCC. To this end, it will make a comparative study with its reporting under the Montreal Protocol by utilizing the framework of "enforceability analysis" [5] as well as the concepts of "scale" and "scaling" [6].

This paper begins with an overview of the reporting requirements, as well as the characteristics of information being sought, under the UNFCCC and the Montreal Protocol. This is followed by the identification of a framework of analysis. After presenting the result, this paper will extend the discussion to the implications for developing capacity for reporting with transparency among developing countries.

\section{BACKGROUND}

\section{A. Reporting Requirements under the UNFCCC}

The Paris Agreement [7], as adopted at the Conference of the Parties (COP) to the UNFCCC in 2015, established an enhanced transparency framework for action and support "in order to build mutual trust and confidence" (Article 13.1). This is also intended to monitor and evaluate the implementation of the Parties' individual nationally determined contributions (NDCs) (Article 13.5), which manifest their action to reduce national emissions and adapt to the impacts of climate change, and are expected to function 
as a key vehicle to ensure implementation of climate actions after 2021.

The current transparency arrangements involving non-Annex I countries (developing countries) under the Convention include national communications (NCs) and biennial update reports (BURs). Submitting NCs is one of the commitments for all Parties under the Convention (Article 4) [8]. NCs provide information on the national greenhouse gas (GHG) inventory, measures to mitigate and facilitate adequate adaptation to climate change, and other relevant information. The Cancun Agreement [9], as adopted at COP16 in Cancun, Mexico, stated that non-Annex I countries should submit their NCs every four years (paragraph 60(b)). This agreement also introduced BURs, which provide an update of the information contained in NCs, including a national GHG inventory (paragraph 60(c)). COP17 in Durban, South Africa [10] agreed that non-Annex I countries should submit their first BUR by December 2014. It also decided that non-Annex I countries shall submit BURs every two years, either as a summary of parts of their NC in the year in which the NC is submitted, or as a stand-alone update report (paragraph 41(f)). The guidelines for the preparation of NCs and BURs have been provided [11]. Financial and technical supports are also made available for developing countries under the Convention [12].

A national GHG inventory is an essential element of both NCs and BURs. It identifies and quantifies a country's anthropogenic sources and sinks of GHGs, thereby being a foundation for accounting and tracking progress towards climate change mitigation goals [13].

\section{B. Reporting Requirements under the Montreal Protocol}

The Montreal Protocol establishes the phase-out schedules for production and consumption of ozone depleting substances (ODS) [14]. National data on ODS is essential for monitoring of the implementation of ODS phase-out, and the success of the Montreal Protocol is reliant on Parties reporting data accurately and on time [15].

There are two principal data requirements under the Montreal Protocol [16]. One is an annual data report to be submitted to the Secretariat of the Montreal Protocol, i.e., the so-called Ozone Secretariat, and the other is a Country Programme report to the Secretariat of the Multilateral Fund for the Implementation of the Montreal Protocol, which is a financial mechanism to help developing countries meet their commitments under the Protocol. While these two reports have mutually different purposes, both require quantitative data on production, imports, and exports of ODS.

Annual data reports must be submitted to the Ozone Secretariat by September 30 each year, and are a legal obligation for all Parties, both developed and developing countries. They are required to provide data on ODS, such as production, imports, exports, destruction, and trade with Non-Parties. The Ozone Secretariat uses the submitted data for assessing each country's compliance with the ODS phase-out schedules agreed under the Protocol, and for tracking global progress in phasing-out ODS [16].

A Country Programme report is a requirement for developing country Parties that receive assistance for a Country Programme from the Multilateral Fund. Such countries are required to provide information by May 1 every year to the Fund Secretariat on progress in the implementation of their Programmes. The data contained in a Country Programme report should be consistent with the data reported to the Ozone Secretariat. The Fund Secretariat uses the submitted data to track the progress in ODS phase-out, and to identify areas where further support may be needed [16].

A handbook on data reporting [16] has been provided. Regional workshops are conducted for technical support. Financial support is also available through the Multilateral Fund.

Table I is a summary of information that developing countries are requested to report under the UNFCCC and the Montreal Protocol.

TABLE I: INFORMATION DEVELOPING COUNTRIES ARE REQUESTED TO REPORT TO THE UNITED NATIONS FRAMEWORK CONVENTION ON CLIMATE Change (UNFCCC) AND THE MONTREAL PRotocol on SubSTANCES THAT DELETE THE OZONE LAYER

\begin{tabular}{ll}
\hline \multicolumn{1}{c}{ UNFCCC } & \multicolumn{1}{c}{ Montreal Protocol } \\
\hline (1) National communication (NC): & (1) Annual data report to the \\
NCs include information on & secretariat of the Montreal \\
national circumstances, & Protocol: \\
greenhouse gas (GHG) & The annual data report contains \\
inventories, vulnerability and & national data on production, \\
adaptation assessment, mitigation & imports, exports, destruction, and \\
assessment, financial resources & trade with Non-Parties of the \\
and transfer of technology, and & controlled substance during the \\
education, training and public & previous year. \\
awareness. & (2) Country Programme report to the \\
(2) Biennial update report (BUR): & secretariat of the Multilateral \\
BURs include an update on GHG & Fund for the Implementation of \\
inventories, information on & the Montreal Protocol: \\
mitigation actions taken and their & The Country Programme report \\
effects, and an outline of & contains data on production, \\
countries' needs and support & imports, and exports of the \\
received. & controlled substance during the \\
(3) National reports under the Paris & previous year. \\
Agreement: & \\
GHG inventory and information & \\
necessary to track progress made & \\
in implementing and achieving its & \\
nationally determined & \\
contribution (NDC). & \\
\hline
\end{tabular}

\section{METHOD}

The Philippines is selected as the target country of the present study. Table II shows the status of submissions of NCs, BURs, and NDC, as of July 2018, by five Southeast Asian countries. The Philippines submitted two NCs in 2000 and 2014, but it has not yet submitted its BUR or NDC, unlike the neighboring countries. On the other hand, all of these countries report as required under the Montreal Protocol [17]. Thus, the Philippines is apparently late in reporting under the UNFCCC, while it submits reports as scheduled under the Montreal Protocol. The present study will probe why this is the case. In doing so, it examines the relative difficulties in production of national reports under the two international regimes. In particular, it considers the relative difficulties of data collection within the country. With regard to reporting under the UNFCCC, this study focuses on a national GHG inventory, as this is an essential element of both NCs and BURs. It is also the foundation for designing a NDC and tracking its implementation. 
TABLE II: YEARS OF SUBMISSIONS OF NATIONAL COMMUNICATIONS (NCS), BIENNIAL UPDATE REPORTS (BURS), AND NATIONALLY DETERMINED CONTRIBUTIONS (NDCS) BY SOUTHEAST ASIAN COUNTRIES AS OF JULY

\begin{tabular}{llrrrrr}
\hline \multicolumn{7}{c}{$2018[18]-[20]$} \\
\hline Indonesia & NC1 & NC2 & NC3 & BUR1 & BUR2 & NDC \\
\hline Malaysia & 2999 & 2011 & 2018 & 2016 & - & 2016 \\
\hline Philippines & 2000 & 2011 & - & 2016 & - & 2016 \\
\hline Thailand & 2000 & 2014 & - & - & - & - \\
\hline Vietnam & 2003 & 2011 & - & 2015 & 2017 & 2016 \\
\hline
\end{tabular}

The present study employed interviews with the National Focal Point on Climate Change as well as the National Ozone Unit in the Philippines. The former is the Climate Change Commission (CCC) at the Presidential Office and the latter is the Philippines Ozone Desk (POD) at the Environment Management Bureau (EMB) of the Department of Environment and Natural Resources (DENR). The interviews were conducted in Manila in June 2018. In each interview, presentations were made by the CCC and the POD on the institutional arrangements and procedures for data collection and reporting under the respective regimes, which were followed by questions and answers. Desk-top reviews were also conducted on relevant documents, including legal documents and national submissions, such as the first and second NCs of the Philippines to the UNFCCC [21], [22]. The data and information obtained from the above interviews and desk-top reviews were then analyzed, using the framework of "enforceability analysis" [5] and the concepts of "scale" and "scaling" [6]. The details of these analytical frameworks will be provided in the relevant sections below.

\section{RESULTS}

\section{A. Reporting by the Philippines under the UNFCCC}

The Philippines signed the UNFCCC in 1992 and ratified it in 1994. The Inter-Agency Committee on Climate Change (IACCC) was established in 1991 to coordinate activities relating to climate change. The IACCC was composed of 15 government agencies and NGO representatives. It was co-chaired by the Secretaries of the DENR and the Department of Science and Technology. The IACCC secretariat was sited in the EMB of the DENR. The EMB used to have only three dedicated staff for the discharge of a secretariat role for the IACCC. With the enactment of the Climate Change Act (the Republic Act 9729) in 2009, however, the CCC was established as a national focal point for the UNFCCC. It is sited in the Presidential Office and chaired by the President. One of its functions is to coordinate, monitor and evaluate the climate change programs and plans of the different government agencies. Today, the CCC has more than a hundred personnel, including technical and administrative staff [23].

The Philippines submitted the first and second NCs in 2000 and 2014, respectively. It has been developing its third NC together with the first BUR since 2016. Although the government relied upon external consultants during the previous reporting cycles, it is now making efforts to internalize the work in order to become able to report in a more sustainable and regular manner.

These efforts are manifested most prominently by the preparation of a national GHG inventory. The Executive Order No. 174 "Philippine Greenhouse Gas Inventory Management and Reporting System" [24] was signed by the President in 2014 to institutionalize the GHG inventory management and reporting system in relevant government agencies. It stipulates the roles and responsibilities of the $\mathrm{CCC}$ and relevant ministries. The $\mathrm{CCC}$ is assigned to be an overall lead body with the following responsibilities: (1) to provide direction and guidance in accounting and reporting of GHG inventories; (2) to develop a system for archiving, reporting, monitoring, and evaluating GHG inventories; and (3) to provide and facilitate continuous capacity-building for GHG inventory preparation. In addition, lead agencies on the sectoral level are assigned as follows: the Department of Agriculture and the Philippine Statistics Authority for the agriculture sector; the Department of Energy for the energy sector; the DENR for the waste, industrial process, and land-use and forestry sectors; and the Department of Transportation and Communications for the transport sector. The sectoral lead agencies are responsible for (1) conducting, documenting, archiving and monitoring sector-specific GHG inventories; and (2) reporting sector-specific GHG inventories to the CCC. Based on this Executive Order, each sectoral lead agency has assigned its own staff for the preparation of the sector GHG inventories and allocated the necessary funds from the regular budgets.

According to [25], the most common methodological approach in GHG inventories is to combine information on the extent to which a human activity takes place, called "activity data" (AD), with coefficients which quantify the emissions or removals per unit of activity, called the "emission factor" (EF), where emissions = $\mathrm{AD} * \mathrm{EF}$. Although all emissions are reported in terms of tons of $\mathrm{CO}_{2}$ equivalent, activity data vary in terms of types, units, and sources. Data collection procedures are necessary for finding existing data, as well as for generating new data by surveys or measurements.

Table III summarizes the data gaps or inconsistencies regarding the national GHG inventory in the Philippines, as indicated by [21] and [26]-[28]. Various types of data gaps or inconsistencies are widely found across different categories. Some may need better utilization of exiting data, while others may require the generation of new data by surveys. In addition, some of the problems concern the country's key categories, which are those with a significant influence on the national GHG inventory in terms of the absolute level or the trend. In the case of the Philippines, they include $\mathrm{CO}_{2}$ removal from changes in forest and other woody biomass stock; $\mathrm{CO}_{2}$ emissions from forest and grassland conversion; $\mathrm{CO}_{2}$ emissions from road vehicles; $\mathrm{CH}_{4}$ emissions from rice production; $\mathrm{CO}_{2}$ emissions from manufacturing industries; $\mathrm{N}_{2} \mathrm{O}$ emissions from agricultural soils; and $\mathrm{CH}_{4}$ emission from enteric fermentation in domestic livestock [29].

TABLE III: DATA GAPS OR INCONSISTENCIES IN THE NATIONAL GREENHOUSE INVENTORY OF THE PHILIPPINES

\begin{tabular}{lc}
\hline Relevant Categories $(*)$ & Data Gaps or Inconsistencies $(* *)$ \\
\hline 1. Energy & $\begin{array}{c}\text { (1) Inconsistencies of available data on fuel } \\
\text { consumption and allocation due to frequent } \\
\text { revisions; and (2) lack of country-specific } \\
\text { emission factors }\end{array}$ \\
\hline 1A Fuel Combustion & Gaps in data for (1) vehicle type and fuel type \\
\hline
\end{tabular}




\begin{tabular}{|c|c|}
\hline Activities & $\begin{array}{l}\text { for vehicle kilometres travelled; and (2) } \\
\text { biomass fuel consumption in households for } \\
\text { reporting as an information item }\end{array}$ \\
\hline $\begin{array}{l}\text { 1B Fugitive } \\
\text { Emissions from } \\
\text { Fuels }\end{array}$ & $\begin{array}{l}\text { Gaps in data for (1) gas vented from oil } \\
\text { production; (2) gas flared from oil } \\
\text { production; (3) crude oil transported; (4) } \\
\text { refinery crude oil throughput; and (5) gas } \\
\text { production }\end{array}$ \\
\hline $\begin{array}{l}\text { 2. Industrial Processes } \\
\text { and Product Use }\end{array}$ & $\begin{array}{l}\text { Lack of reliability of data from industries in } \\
\text { general }\end{array}$ \\
\hline 2A Mineral Industry & $\begin{array}{l}\text { Gaps in data for production in (1) paper and pulp } \\
\text { industry; and (2) beverage industry }\end{array}$ \\
\hline $\begin{array}{l}\text { 2B Chemical } \\
\text { Industry }\end{array}$ & Gaps in itemized chemical production data \\
\hline 2C Metal Industry & Gaps in data for ferroalloy production \\
\hline $\begin{array}{l}\text { 3. Agriculture, Forestry, } \\
\text { Other Land Use }\end{array}$ & $\begin{array}{l}\text { Lack of country-specific emission factors and } \\
\text { data }\end{array}$ \\
\hline 3A Livestock & $\begin{array}{l}\text { Gaps in data for (1) livestock population by } \\
\text { animal species/category; and (2) manure } \\
\text { management system usage }\end{array}$ \\
\hline 3B Land & $\begin{array}{l}\text { (1) Various inconsistencies in available data on } \\
\text { land use and land use change; (2) lack of } \\
\text { distinctions of forest types; (3) data gaps on } \\
\text { soil carbon stocks; (4) data gaps on biomass } \\
\text { burning; and (5) lack of reliability in } \\
\text { available data on biomass carbon transferred } \\
\text { to different fates }\end{array}$ \\
\hline $\begin{array}{l}\text { 3C Aggregate } \\
\text { Sources and } \\
\text { Non- } \mathrm{CO}_{2} \\
\text { Emissions } \\
\text { Sources on Land }\end{array}$ & $\begin{array}{l}\text { Gaps in data for (1) synthetic nitrogen fertilizer } \\
\text { applied to soils; and (2) crop residues }\end{array}$ \\
\hline \multicolumn{2}{|l|}{ 4. Waste } \\
\hline $\begin{array}{l}\text { 4A Solid Waste } \\
\text { Disposal }\end{array}$ & $\begin{array}{l}\text { Gaps in data for (1) waste generation in rural } \\
\text { areas; and (2) waste collection in the areas } \\
\text { outside Manila }\end{array}$ \\
\hline $\begin{array}{l}\text { 4D Wastewater } \\
\text { Treatment and } \\
\text { Discharge }\end{array}$ & $\begin{array}{l}\text { Gaps in data for (1) sludge treatment; and (2) } \\
\text { wastewater handling practices in the areas } \\
\text { outside Manila }\end{array}$ \\
\hline $\begin{array}{l}\text { 4D2 Industrial } \\
\text { Wastewater } \\
\text { Treatment } \\
\text { and } \\
\text { Discharge } \\
\end{array}$ & $\begin{array}{l}\text { Gaps in data for (1) wastewater generated and } \\
\text { chemical oxygen demand; and (2) the amount } \\
\text { of } \mathrm{CH}_{4} \text { that is flared or recovered for energy } \\
\text { use }\end{array}$ \\
\hline
\end{tabular}

Notes: (*) Categorized according to the 2006 Intergovernmental Panel on Climate Change (IPCC) Guidelines for National Greenhouse Gas Inventories [25]. (**) Data gaps or inconsistencies as indicated by [21] and [26]-[28].

\section{B. Reporting by the Philippines under the Montreal Protocol}

The Philippines signed the Montreal Protocol in 1988 and ratified it in 1991. The country committed itself to gradually reduce and eventually phase out its consumption of ODS following the agreed timetable. The Protocol defines consumption as production plus import minus export. Since the Philippines is neither a producer nor an exporter of ODS; its consumption is equal to its imports.

The POD is the national coordinator, the so-called "national ozone unit", for the implementation of the Protocol. It is sited in the EMB of the DENR. The POD is charged with issuance of clearance for all ODS imports, except pesticide methyl bromide, which is monitored and controlled by the Fertilizer and Pesticide Authority (FPA) of the Department of Agriculture. The Bureau of Customs cooperates with the POD and the FPA by checking whether importers have the necessary permits.

Based on the Republic Act 6969 "Toxic Substances and Hazardous and Nuclear Wastes Control Act of 1990", the DENR has issued the Administrative Order No. 2013-25 "Revised Regulations on the Chemical Control Order for
Ozone Depleting Substances“ [30]. This Order directs importers of ODS, except methyl bromide, to register and apply for permits from the DENR. According to [31], there are 54 registered importers for the years 2009 - 2010, many of which are foreign-owned. Dealers, retailers, and resellers of ODS are also mandated to be registered with the DENR, in addition to being accredited by the Department of Trade and Industry (DTI). Service providers, such as those who refill refrigerators and other ODS-using equipment, are required to be registered as well in order to purchase ODS. A certificate of registration may only be granted by the DENR upon showing proof that the service provider has been certified by the Technical Education and Skills Development Authority (TESDA) in the case of individual mechanics, or accredited by the DTI in the case of service/repair shops. In the meantime, companies that use ODS in their production processes, such as those which produce air-conditioners and refrigerators, are encouraged to shift to alternative technologies. Methyl bromide, on the other hand, is restricted according to the FPA Circular No. 04 Series of 1989 [32].

The POD submits annual data reports to the Ozone Secretariat and Country Programme reports to the Fund Secretariat every year. In order to produce these national reports, the POD collects data on ODS through the registration system described above. The registered importers, dealers, retailers, and resellers are obliged to keep a record of all ODS transactions and prepare an annual report according to the prescribed format, which must be submitted to the POD by January in the following year. The registered service providers are also required to keep a record of all transactions, including information on the quantity of recovered ODS, which must be validated by the POD [30].

Thus, the POD collects information on the permits granted and annual feedback reports from the registered importers. The POD is thereby able to calculate country-wide data on imports from the company-specific information. Customs data are also useful for double-checking of the collected data on imports. As for consumption data, the POD collects information from the registered service providers. In addition, the POD keeps an inventory of companies that use ODS in their production processes for survey as necessary. Such companies, according to the POD, are limited in number and readily identifiable.

Those who fail to report as obliged by the above-mentioned Administrative Order will be penalized by cancellation of their registration with the DENR. In addition, they may also face cancellation of the DTI accreditation and/or the TESDA certificate [30].

Reporting to the Ozone and Fund secretariats and the associated data collection has become a routine for the POD.

At the time of this writing, the POD has a staff of six, including four IT and administrative staff, all of whom are funded by the Multilateral Fund. According to the POD, there is no serious difficulty faced in the data collection and reporting. Assistance under the Montreal Protocol, such as advice provided by the Ozone Secretariat and through regional workshops, has contributed to the relevant capacity development of the POD staff.

\section{Enforceability}


As described in the previous sections, the Philippines has the Executive Order No. 174 as a basis for the national GHG inventory reporting, and the DENR Administrative Order No. 2013-25, for reporting on imports and use of ODS. It is a common observation that some rules are easier to enforce than others, and there are factors which tend to make enforcement easier or more difficult [5]. As elaborated by [5], these factors can be more generally termed (1) cadasterability or listability, (2) conduitability or capacity for canalization, (3) standard unequivocality, (4) reinforceability, and (5) cross-sanctions.

Cadasterability or listability means that the population to which a scheme applies is readily identifiable without minute and case-specific research. It also means that the enforcee population is relatively stable, since it will obviously be harder to achieve if that population is highly volatile. Conduitability or a capacity for canalization means that the blameable units are stable, clearly defined, specific rather than diffuse, and above all, relatively few in number, so that the enforcing bureaucracy can operate through a relatively small number of channels or bottlenecks in which oversight can be economically applied. Standard unequivocality means enforcement rests on standards or values which can be ascertained relatively economically as well as objectively. Reinforceability means cross-checking oversight from different vantage points, established for different purposes. Cross-sanctions means that parties which contemplate breaking a rule are put into a position where they must offset the advantage of violating one rule against corresponding disadvantages which automatically come into play [5].

Table IV is a summary comparison of data collection for national reporting under the UNFCCC and the Montreal Protocol in terms of the above-indicated five factors. It shows that the DENR Administrative Order No. 2013-25 is easier to enforce, thereby making data collection for national reporting under the Montreal Protocol relatively easier to implement. As discussed by [5], awareness of such factors can help us understand why the Philippines does better in reporting under the Montreal Protocol.

\section{Scale and Scaling}

The concepts of "scale" and "scaling" also enable us to explain why the Philippines is apparently late in reporting under the UNFCCC unlike the case under the Montreal Protocol. As defined by [6], scale is treated as a ruler along which relative magnitude can be measured. There are many different scales. One of the most important scales in environmental governance is the administrative scale. Levels are points along a scale. Scaling is the act of moving up or down from one level to another on a particular scale.

TABLE IV: ENFORCEABILITY ANALYSIS [5] ON DATA COLLECTION FOR NATIONAL REPORTING IN THE PHILIPPINES

\begin{tabular}{ccc} 
Factors for & NATIONAL REPORTING IN THE PHILIPPINES \\
enforceability & Data collection for & Data collection for reporting \\
& $\begin{array}{l}\text { reporting national } \\
\text { greenhouse gas } \\
\text { (GHG) imventories }\end{array}$ & $\begin{array}{l}\text { impopteting substances } \\
\text { (ODS) }\end{array}$ \\
\hline Cadasterability & Various data sources & Under the Administrative \\
& exist. While activity & Order No. 2013-25 of the \\
& data may be improved & Department of \\
through better & Environment and Natural \\
& utilization of existing & Resources (DENR), \\
data in some cases, & importers, distributors, \\
\hline
\end{tabular}

\begin{tabular}{|c|c|c|}
\hline & $\begin{array}{l}\text { new data need to be } \\
\text { generated by sample } \\
\text { surveys and } \\
\text { measurements in } \\
\text { others. For } \\
\text { country-specific } \\
\text { emission factors, } \\
\text { detailed research is } \\
\text { often required. }\end{array}$ & $\begin{array}{l}\text { and service providers of } \\
\text { ODS, except methyl } \\
\text { bromide, must be } \\
\text { registered with the } \\
\text { DENR. The Philippines } \\
\text { Ozone Desk (POD) } \\
\text { collects data on ODS } \\
\text { transactions through the } \\
\text { above registration system } \\
\text { without conducting } \\
\text { case-specific research. } \\
\text { Companies that use ODS } \\
\text { in their production } \\
\text { processes are limited in } \\
\text { number and readily } \\
\text { identifiable. The POD } \\
\text { keeps an inventory of } \\
\text { such companies for } \\
\text { survey as necessary. }\end{array}$ \\
\hline Conduitability & $\begin{array}{l}\text { Various data sources } \\
\text { exist. Data collection } \\
\text { methods and } \\
\text { procedures tend to } \\
\text { evolve over time with } \\
\text { improvement of GHG } \\
\text { inventories. } \\
\end{array}$ & $\begin{array}{l}\text { Those who are obliged to } \\
\text { report to the POD are } \\
\text { clearly specified through } \\
\text { the registration system. }\end{array}$ \\
\hline $\begin{array}{l}\text { Standard } \\
\text { unequivocality }\end{array}$ & $\begin{array}{l}\text { While GHG emissions } \\
\text { and removals are } \\
\text { reported in terms of } \\
\text { tons of } \mathrm{CO}_{2} \\
\text { equivalent, activity } \\
\text { data widely vary in } \\
\text { terms of units. }\end{array}$ & $\begin{array}{l}\text { Quantities of imported } \\
\text { and/or distributed ODS } \\
\text { are reported to the POD in } \\
\text { terms of kilograms. }\end{array}$ \\
\hline Reinforceability & $\begin{array}{l}\text { The Executive Order No. } \\
174 \text { does not impose } \\
\text { any legal obligations } \\
\text { on companies and } \\
\text { other } \\
\text { non-governmental } \\
\text { actors to provide data. } \\
\text { In many cases, } \\
\text { inventory compilers } \\
\text { need to rely upon data } \\
\text { available at the } \\
\text { national statistical } \\
\text { agency and/or data } \\
\text { submitted by } \\
\text { companies for other } \\
\text { regulatory purposes. }\end{array}$ & $\begin{array}{l}\text { Licensing and monitoring } \\
\text { system for imports of } \\
\text { ODS is in place. The POD } \\
\text { collects information on } \\
\text { the permits granted and } \\
\text { annual feedback reports } \\
\text { from the registered } \\
\text { importers. The Bureau of } \\
\text { Customs cooperates with } \\
\text { the POD by checking } \\
\text { whether importers have } \\
\text { the necessary permits. } \\
\text { Customs data are also } \\
\text { useful for } \\
\text { double-checking of the } \\
\text { collected data on imports. }\end{array}$ \\
\hline Cross-sanctions & $\begin{array}{l}\text { The Executive Order No. } \\
174 \text { does not impose } \\
\text { any legal obligations } \\
\text { on companies and } \\
\text { other } \\
\text { non-governmental } \\
\text { actors to provide data. }\end{array}$ & $\begin{array}{l}\text { Those who fail to report will } \\
\text { be penalized by } \\
\text { cancellation of the } \\
\text { registration with the } \\
\text { DENR, thereby not being } \\
\text { able to import, distribute } \\
\text { and/or purchase ODS any } \\
\text { more. In addition, they } \\
\text { may also face cancellation } \\
\text { of accreditation by the } \\
\text { Department of Trade and } \\
\text { Industry. }\end{array}$ \\
\hline
\end{tabular}

As related in the previous sections, the institutional arrangements for the issue of climate change have been changing in recent years, while those for ozone protection have been stable in the Philippines. The motivation for upscaling, as presented by [6], is relevant to the case of climate change in the Philippines (Table V). Upscaling helps ensure that a number of influential factors are covered in the definition and analysis of a problem, thus helping better solutions. It is also consistent with a need to be inclusive and create greater legitimacy in the policymaking process. As illustrated in Fig. 1, with the enactment of the Climate Change Act and the resulting creation of the CCC, the 
government scaled up the issue of climate change on the administrative scale. This is exemplified by the fact that, whereas the IACCC secretariat was sited in the DENR-EMB, the $\mathrm{CCC}$ is now sited in the Presidential Office. The Executive Order No. 174 also assigned the CCC to be an overall lead agency for the preparation of national GHG inventories. Scaling up the issue of climate change on the administrative scale is intended to ensure that all the relevant government agencies and other stakeholders are engaged and to make them accountable for the outcome obtained.

With the upscaling on the administrative scale, there is a need for more resources for guidance, coordination, monitoring, and evaluation. This is evidenced by a significant increase in the number of dedicated personnel at the CCC. There are also stronger needs for capacity development. The development of capacity at the CCC and relevant agencies for producing and archiving GHG inventories on their own, for example, has become imperative.

According to [33], sustainable national GHG inventories involve (1) enhancement of individual and organizational capacities for a lead agency to manage the national GHG inventory process, as well as for sectoral coordinating institutions to produce sector-specific GHG inventories; (2) development of institutional mandates, data-sharing agreements, and processes for archiving inventory information; (3) allocation of sustained financial resources; and (4) establishment of an iterative approach to improving the national GHG inventory system. These cannot be easily solved, however. Figure 2 depicts two loops relating to the production of national GHG inventories. Loop 1 (L1) is a cycle for regularly updating national GHG inventories, completion of which every two years is internationally required. Loop 2 (L2) is a cycle of capacity development for national GHG inventories, in which every cycle is expected to result in the production of better GHG inventories than the preceding cycles. In the case of the Philippines, which is in the process of upscaling the issue of climate change, the two loops have not yet matched in terms of time duration per cycle. At this stage, the time duration per cycle in L2 is longer than that in L1.

In contrast, the POD remains a unit within the DENR-EMB, with a limited number of staff. Reporting under the Montreal Protocol and the associated data collection has become a routine and well-established task for the POD. There are motivations for keeping the levels on the administrative scale low, even if not scaling them down. As discussed by [6], this derives from a desire to make use of existing problem-solving institutions, as these often include processes designed to ensure legality and accountability.

TABLE V: MOTIVATIONS FOR UPSCALING AND DOWNSCALING Motivations as presented by [6] Case in the Philippines Scaling up to include other actors, The Climate Change Act (the Republic creating greater political legitimacy

\begin{tabular}{ll}
\hline & $\begin{array}{l}\text { Scaling up on the administrative } \\
\text { scale in the Philippines is intended } \\
\text { to ensure that the relevant } \\
\text { stakeholders are involved and to } \\
\text { make them accountable for the } \\
\text { outcome obtained. }\end{array}$ \\
\hline $\begin{array}{l}\text { Scaling down to use existing } \\
\text { problem-solving institutions } \\
\text { and thereby to take advantage } \\
\text { of built-in processes designed } \\
\text { to ensure legitimacy, legality, } \\
\text { transparency, and }\end{array}$ & $\begin{array}{l}\text { The Administrative Order No. 2013-25 } \\
\text { iscountability }\end{array}$ \\
$\begin{array}{l}\text { distributors of ozone-depleting } \\
\text { substances, except methyl bromide, } \\
\text { to be registered. Through this }\end{array}$ \\
registration system, data is collected \\
by the Philippines Ozone Desk \\
(POD) to produce national reports \\
under the Montreal Protocol. As the \\
reporting and associated data \\
collection has become a routine and \\
established task for the POD, there \\
is no motivation for scaling up this \\
issue on the administrative scale.
\end{tabular}

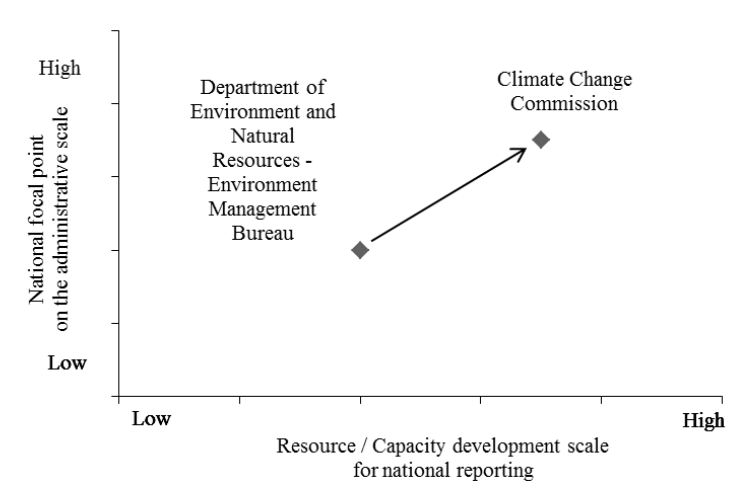

Fig. 1. Upscaling of the issue of climate change in the Philippines.

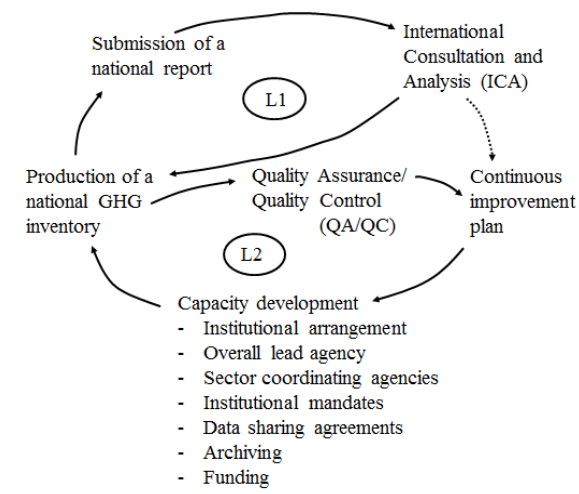

Fig. 2. Two loops for reporting national GHG inventories.

\section{DISCUSSION}

Using the framework of enforceability analysis and the concepts of scale and scaling, this paper explained why the Philippines is apparently late in reporting under the UNFCCC, unlike the case in its reporting under the Montreal Protocol. However, it has not explained why the Philippines is lagging behind the neighboring countries in Southeast Asia in terms of frequency of reporting under the UNFCCC (Table II). As this question is beyond the scope of this paper and will be addressed in further research, some potential factors are only indicated here. One may concern the data gaps or inconsistencies, as listed in Table III, for the national GHG inventory in the Philippines, which may be more difficult to overcome than those in the neighboring countries. Another potential factor may be related to the stage of the relevant capacity development. As discussed by [1], governments 
initially may lack the informational infrastructure for data collection and reporting. Once created, however, such infrastructures develop and become embedded in bureaucratic missions and standard operating procedures. The Philippines may have further to go towards achieving such a point than the neighboring countries. Lastly, the late reporting may be an unintended side effect of the strong emphasis on stakeholder participation in the country. As discussed in the previous section, upscaling of the issue of climate change is consistent with the need to create a more inclusive policy consultation process, which, however, takes time.

The future transparency framework outlined in the Paris Agreement is likely to increase the overall frequency and quality of information [34]. The capacities of developing countries to update national reports on a regular and sustainable basis, however, are limited. Capacity development is, therefore, important if the enhanced transparency framework is to be successfully implemented. However, [35] cautions against too much interest on the side of donors in "getting things done" ("getting national reports submitted" in the context of the present paper). Capacity development is a process of endogenous change and requires a context-sensitive and differentiated approach. There is an increasing need for donors to find a good balance between assisting developing countries with the delivery of reports for transparency and facilitating their longer-term capacity development.

\section{CONCLUSION}

The Philippines is apparently late in reporting under the UNFCCC, while it submits reports as scheduled under the Montreal Protocol. By using the framework of enforceability analysis and the concepts of scale and scaling, the present study probed why this is the case. Further research is required to address the question why the Philippines is lagging behind the neighboring countries in Southeast Asia in terms of frequency of reporting under the UNFCCC.

\section{ACKNOWLEDGMENT}

The opinions expressed in this paper are those of the authors and do not necessarily represent the views of the organizations to which the authors belong.

\section{REFERENCES}

[1] A. Chayes and A. H. Chayes, The New Sovereignty: Compliance with International Regulatory Agreements, Cambridge, MA: Harvard University Press, 1995, ch. 7, pp. 154-173.

[2] J. H. Ausubel and D. G. Victor, "Verification of international environmental agreements," Апnu. Rev. Energy Environ., vol. 17, pp. $1-43,1992$

[3] R. B. Mitchell, "Sources of transparency: Information systems in international regimes," International Studies Quarterly, vol. 42, pp. 109-130, 1998.

[4] United States General Accounting Office, International Environment: Strengthening the Implementation of Environmental Agreements, Washington, DC: GAO, 1992.

[5] C. Hood, Administrative Analysis: An Introduction to Rules, Enforcement and Organization, Sussex, UK: Wheatsheaf Books, 1986, ch. 3, pp. 48-86.

[6] J. Gupta, "Global change: Analyzing scale and scaling in environmental governance," Institutions and Environmental Change:
Principal Findings, Applications, and Research Frontiers, Cambridge, MA: The MIT Press, 2008, ch. 7, pp. 225-258.

[7] UNFCCC. (2015). Paris Agreement. [Online]. Available: https://unfccc.int/sites/default/files/english_paris_agreement.pdf

[8] UNFCCC. (1992). United Nations Framework Convention on Climate Change. [Online]. Available: https://unfccc.int/sites/default/files/conveng.pdf

[9] UNFCCC. (2010). Report of the Conference of the Parties on its Sixteenth Session, Held in Cancun from 29 November to 10 December 2010. [Online]. Available: http://unfccc.int/resource/docs/2010/cop16/eng/07a01.pdf\#page=2

[10] UNFCCC. (2011). Report of the Conference of the Parties on its seventeenth session, held in Durban from 28 November to 11 December 2011. [Online]. Available: http://unfccc.int/resource/docs/2011/cop17/eng/09a01.pdf\#page=39, Decision 2/CP.17.

[11] UNFCCC. (2018). Guidelines and Manuals for the Preparation of non-Annex I National Reports and International Consultation and Analysis. [Online]. Available: https://unfccc.int/process-and-meetings/transparency-and-reporting/re porting-and-review-under-the-convention/support-for-developing-cou ntries/guidelines-and-manuals-for-the-preparation-of-non-annex-i-nati onal-reports-and-international

[12] UNFCCC. (2018). Financial and Technical Support for Non-Annex I Parties. [Online]. Available: https://unfccc.int/process/transparency-and-reporting/reporting-and-re view-under-the-convention/support-for-developing-countries/financia 1-and-technical-support-for-non-annex-i-parties

[13] C. Hood, G. Briner, and M. Rocha, GHG or Not GHG: Accounting for Diverse Mitigation Contributions in the Post-2020 Climate Framework, Paris: OECD/IEA, 2014.

[14] UN. (1987). Montreal Protocol on Substances that Deplete the Ozone Layer. [Online]. Available: https://treaties.un.org/doc/Publication/UNTS/Volume\%201522/volum e-1522-I-26369-English.pdf

[15] UNEP. (2018). Data Reporting and Surveys. [Online]. Available: http://web.unep.org/ozonaction/what-we-do/data-reporting-and-surve ys

[16] Handbook on Data Reporting under the Montreal Protocol, UNEP, Paris, France, 1999.

[17] UNEP. (2014). Report of the Implementation Committee under the Non-Compliance Procedure for the Montreal Protocol on the Work of Its Fifty-Third Meeting. [Online]. Available: http://42functions.net/Meeting_Documents/impcom/IMPCOM-53-4E. pdf

[18] UNFCCC. (2018). National Communication Submissions from Non-Annex I Parties. [Online]. Available: https://unfccc.int/process-and-meetings/transparency-and-reporting/re porting-and-review-under-the-convention/national-communications-a nd-biennial-update-reports-non-annex-i-parties/national-communicati on-submissions-from-non-annex-i-parties

[19] UNFCCC. (2018). Biennial Update Report submissions from Non-Annex I Parties. [Online]. Available: https://unfccc.int/process-and-meetings/transparency-and-reporting/re porting-and-review-under-the-convention/national-communications-a nd-biennial-update-reports-non-annex-i-parties/biennial-update-report -submissions-from-non-annex-i-parties

[20] UNFCCC. (2018). Interim NDC Registry. [Online]. Available: http://www4.unfccc.int/ndcregistry/Pages/Home.aspx

[21] UNFCCC. (1999). The Philippines' Initial National Communication on Climate Change. [Online]. Available: https://unfecc.int/documents/139218

[22] UNFCCC. (2014). Second National Communication to the United Nations Framework Convention on Climate Change: Philippines. [Online]. Available: https://unfccc.int/documents/139241

[23] S. G. Recabar, "Climate reports: Philippines case," presented at the meeting with the Climate Change Commission, Manila, Philippines, June 18, 2018.

[24] The Lawphil Project. (2018). Executive Order No. 714. [Online]. Available:

https://www.lawphil.net/executive/execord/eo2014/eo_174_2014.htm 1

[25] 2006 IPCC Guidelines for National Greenhouse Gas Inventories, IPCC National Greenhouse Gas Inventories Programme, Kanagawa, Japan, 2006.

[26] R.V. Francisco, "Greenhouse Gas Inventory of the Philippines: Interim Report," Greenhouse Gas Emission Inventories: Interim Results from 
the U.S. Country Studies Program, Switzerland: Springer, 1996, pp. 189-199.

[27] D. Macandog. (2003). GHG Inventory in the Philippines. [Online]. Available: http://www-gio.nies.go.jp/wgia/wg1/pdf/wg1_17.pdf

[28] J. A. Goco. (2009). Developing the Philippines GHG Inventory: Opportunities, Challenges and Next Steps. [Online]. Available: https://www.env.go.jp/en/earth/ap-net/documents/seminar/18th/3-3_P hilippines_Ms.JoyGoco.pdf

[29] S. G. Recabar. (2013). Mitigation Activities - Philippines. [Online]. Available:

http://www.nre.gov.my/sites/lecbnre/Documents/NAMA-MRV/2Intro ductory/6b. National Context and Arrangement for Implementation of NAMAs (The Experience of Philippines).pdf

[30] POD. (2013). Revised Regulations on the Chemical Control Order on Ozone Depleting Substances. [Online]. Available: http://pod.emb.gov.ph/wp-content/uploads/2016/04/DAO-2013-25-Re vised-Regulation-on-CCO.pdf

[31] POD. (2018). List of Registered Importer of Ozone Depleting Substances and Its Alternatives Chemical for year 2009-2010. [Online] Available: http://119.92.161.2/philozone/news/Registered.pdf

[32] FPA. (2018). Pesticide Regulation Division. [Online]. Available: http://fpa.da.gov.ph/index.php/regulatory/pesticide-division

[33] C. Breidenich, Improving Reporting of National Communications and GHG Inventories by Non-Annex I Parties under the Climate Convention, New York, NY: Natural Resources Defence Council, 2011.

[34] G. Briner and S. Moarif, Unpacking Provisions Related to Transparency of Mitigation and Support in the Paris Agreement, Paris: OECD/IEA, 2016.

[35] N. Keijzer, Unfinished Agenda or Overtaken by Events? Applying Aidand Development-Effectiveness Principles to Capacity Development Support, Bonn: Germany: Deutsches Institut für Entwicklungspolitik $\mathrm{gGmbH}, 2013$.

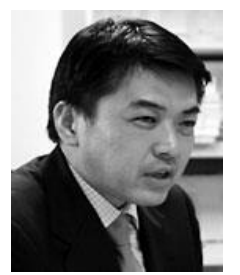

Masato Kawanishi obtained a doctor of engineering degree from Ibaraki University, Japan in 2014, a master of science degree from Imperial College London, UK in 2004, and a master of business administration degree from Boston University, USA in 1993.

$\mathrm{He}$ is senior advisor on climate change for Japan International Cooperation Agency (JICA), Tokyo, Japan.
Dr. Kawanishi co-edited "Climate Change Adaptation and International Development: Making Development Cooperation More Effective" (London, UK: Earthscan, 2010) with Prof. Ryo Fujikura and "Climate Change Policies and Challenges in Indonesia" (Tokyo, Japan: Springer, 2016) with Prof. Shinji Kaneko.

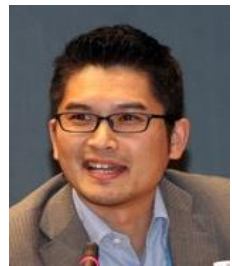

Makoto Kato obtained a master of laws degree from Kobe University Graduate School of International Cooperation Studies, Japan in 2001.

$\mathrm{He}$ is a member of the Board of Directors and Principal Researcher of the Overseas Environmental Cooperation Center, Japan (OECC), Tokyo, Japan. He has been the lead negotiator of capacity-building agenda for the Delegation of Japan in the UN Climate

Change Negotiation

Mr. Kato co-authored "Operationalising MRV of Support: Analysis of Finance, Technology and Capacity Building Support" (Hayama, Japan: IGES, 2011) with Mr. Koji Fukuda.

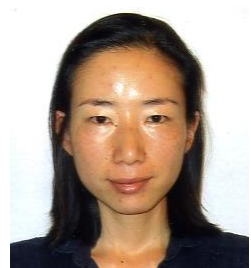

Emiko Matsuda obtained Doctor of Agricultural Science and Master of Science degrees from Tohoku University in 2005 and 2002, respectively.

She is senior researcher in the Overseas Environment Cooperation Center, Japan, lecturer (part-time) in Gakushuin University and visiting research fellow at United Nation University, Institute for the advanced study of sustainability (UNU-IAS)

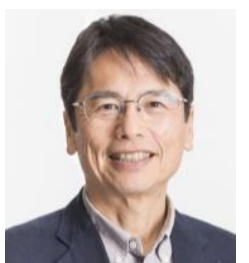

Ryo Fujikura obtained a doctor of natural science degree from Innsbruck University, Austria in 1982 and a Master of Science degree from the University of Tokyo in 1980.

He is professor of Faculty of Sustainability Studies, Hosei University, Tokyo, Japan. Prof. Fujikura co-edited "Climate Change Mitigation and International Development Cooperation" (London, UK: Earthscan, 2012) with Dr. Tomoyo Toyota and "Resettlement Policy in Large Development Projects" (Oxford, UK: Routledge, 2015) with Prof. Mikiyasu Nakayama. 